\title{
Cruzando fronteiras na América Latina
}

\author{
Marcar diferenças, cruzar \\ fronteiras.
}

FRANCO, Jean. Tradução: Ala i Garcia Diniz.

Florianópolis: Mulheres; Belo Horizonte: Ed. PUC Minas, 2005. 181 p.

A Segunda Onda Feminista, caracterizada pela instituc iona lização do Ano Internacional da Mulhere marcada pornovas propostas para esse movimento, é temátic a propulsora de um grande número de trabalhos acadêmicos. Concomitantemente ao desenvolvimento desse tema, nos deparamoscom a perspectiva teórica de gênero, que a partirda déca da de 1980 passa a figurar com maior visibilidade nos meios universitá rios.

É nessa linha que Jean Franco desenvolve os artigos que compõem o livro Marcar diferenças, cruzar fronteiras. Publica do no a no de 1996 em Santiago do Chile pela Editorial Cuarto Próprio, a obra ganha uma edição brasileira apenas no ano de 2005, em uma parceria entre a Editora PUC Minas e a Editora Mulheres. Nascida na Inglaterra, Jean Franco é conhecida pesquisadora de literatura hispanoa meric ana e engajada com os movimentos de esquerda. Crítica em busca do direito de interpretação das mulheres, conquista espaço nos Estados Unidos na área de estudos latinoa meric a nos, trazend o como bagagem os estudos cultura is ingleses. Nos seis artigos public ados nessa coletânea, ela deixa claro seu interesse pela literatura, pelas obras de arte, mas, princ ipa Imente, pelos meios de comunic ação de massa, resultando em uma produção textual militante.

No primeiro artigo selecionado para essa publicação, Jean Franco trata da figura de La 
Malinche, também conhecida pela literatura como Dona Maria, a mante e intérp rete de Cortês. Trazendo as formas como essa personagem foi narrada por autores como Octavio Paz, Tzvetan Todorov, Stephen Greenblat, entre outros, a autora a presenta o simbolismo que envolveu La Ma linche em obras que tematizaram a conquista $d a$ América.

Eventualmente amante de Cortês, mãe de seu filho bastardo legitima do por dec reto papal, intérprete das negociações entre indígenas e espanhóis, mais poderoso membro da comunidade indígena depois de Montezuma, considerada traidora pelos astecas, Dona Maria foi retratada pela literatura sob um prisma muito variado no qual, segundo J ean Franco, ela pode serca rac teriza da como símbolo transfigura do do multic ultura lismo. Essa personagem encontra-se entre o ser indígena e o ser espanhol, ou, como rela ta a autora, ela é o "grotesco híbrido". Tendo como foco a literatura latino-americana e as questões de gênero, Jean Franco mostra como a conquista colonialista se toma mestiçagem. Dessa forma, a autora se debruça sobre essa questão pós-colonialista, na qual La Malinche encontra-se até hoje estigmatizada pela basta rdização dos indíg enas mexic a nos.

Em seu segundo artigo, Jean Franco trabalha com a iconização de Frida Kahlo, tomando como ponto de partida a campanha cultural e public itária realizada pelo México no outono de 1990. Essa campanha levou para Nova York um grande número de exposições nas qua is as obras das mulheres fizeram a ponte entre 0 antigo México revolucionário e o novo México, menos agressivo diante da política estrangeira. Foi na introdução do catálogo de uma das exposições de maior sucesso que Octavio Paz, um dos planejadores dessa amostra, intitulada "México: Esplendores de Trinta Séculos", apresentou a figura da Virgem como ícone pacifista da relação mexicana com os Estados Unidos.

Contudo, como principal figura da campanha publicitária dessa exposição fol escolhida Frida Kahlo, ficando sua obra Autoretra to com Monos presente em vários mura is e revistas. As problemáticas tomadas como de âmbito privado, muito fortes nas obras de Frida Kahlo, haviam se tornado, além de públicas, public itárias; resultando, a partir dessa escolha, na substituição de um México nacionalista por uma representação de um México de exuberâncias e exotismos.

No capítulo seguinte, a autora trabalha com a publicidade da literatura de massa nos Estados Unidos voltada às mulheres, compreendida em dois moldes: as novelas românticas, histórias fantasiosas para consumidoras em potencial; e as histórias em quadrinhosem forma to de novelas, dirigidas às mulheres participantes da força de trabalho. No primeiro desses estilos literários as mulheres são convidadas a inibirem sua inteligência, pois somente a tra vés da supressã 0 de seu lado pensante e da negação de sua carreira profissional o final feliz da história pode ser concretizado. Dessa forma, a novela romântica, ou também caracterizada por Jean Franco como romance rosa, tem como públicoalvo mulheres de classe alta num processo de conciliação entre seu desejo individual e sua a ceitação social. Em contrapartida, a novela semanal, literatura direcionada para as classes baixas, denomina da pela autora como romance vermelho, tem como característica o sacrifíc io do final romântico em benefício da carreira profissional e da emancipação, o que livrará a personagem de uma situa ção fa miliar violenta.

Através da cultura de massa a diferença social entre esse público leitor é acentuada e, segundo Jean Franco, esse processo segue conforme os moldes da divisã o intemacional do trabalho. Em países latino-americ anos como o Brasil e o Méxic o traçar uma proposta literária de mulheres consumid oras to ma-se muito difíc il, uma vez que elas encontram-se direcionadas ao mercado de trabalho. Contudo, a autora nos aponta a incorporação das mulheres na sociedade pormeio dasnovelas semanais, o que, em contrapartida, confina mulherese homens na representação de trabalhadores oprimidos.

Em "Matar sacerdotes, freiras, mulheres e crianças", quarto capítulo do livro, Jean Franco escreve sobre a dessacra lização de deteminados símbolos pelos governos militares na América Latina. A Igreja e a família sempre foram consideradas instituições fortes e assinaladas como locais de imunidade dentro do regime militar, mas, segund o a autora, esse espaço perde seu poder durante os anos sessenta. Em resposta à s guemilha sos exérc itos se a primora $m$, passando a praticar novos métodos de tortura e a se especializarna prática do desa pa recimento. Para Franco, esse ponto teria ocasionado a abstração dessa s instituiç ões sa cra liza das, fa zend o com que tanto freiras, sacerdotes, mulheres e crianças passassem a figurar como personagens de atentados militares. Contudo, não podemos deixar de ressaltar que, se por um lado essas instituições foram a meaçadas, a lgreja e as mães 
tomaram-se símbolos de resistência, abrigando pessoas perseguidas pela ditadura e reivindicando informações sobre familiares desaparecidos.

No quinto capítulo do livro é estudada a a tual partic ip ação das mulheres nos movimentos sociais, que para a autora foi alterada com a reestruturação das relações que se modificam diante de um regime militar e diante de um perío do de crise ocasiona do pela dívida extema. J ean Franco traça um panorama das dificuldades encontradas pelas mulheres para atingirem um espaço de atuação pública e política, muito limita do mesmo em meio à esquerda. As mulheres sempre estiveram muito associadas à noção de privado (que porsua vezé tomado como rotineiro, banal), impedindo-as de se constituírem enquanto sujeitos públicos, dotados de autoridade para realizar uma obra testemunhal que tenha como c a ráter a sua a utorida de interp reta tiva. Contudo, o que há de mais interessante nesse artigo de Franco é a extrapolação das concepções de gênero. Sua atenção encontra-se focada no pluralismo que vivenciamos atualmente, que estimula as diferenças e faz das diversas categorias de análise histórica - como gênero, classe e etnia - indissociá veis.

Trazendo a questão da sexualidade, J ean Franco introduz o último capítulo, que tem por objetivo tratardas recentes tendências na teoria feminista. Abordando as noções essencialista e construcionista a respeito do gênero, a autora busca em teóric as como Dona Ha raway e Judith Butler como se deu o processo de rompimento com a noção de heterossexualida de obriga tória, utilizando como pano de fundo para essa discussão um pastiche de obra de arte, filmes e livros que trazem à tona as diversas performances de gênero. Não necessariamente associados a liberação sexual e concessão de direitos, tra vestis, homossexua is, transexua is, prostitutas fazem parte cada vez mais do cenário cultural la tinoa meric ano. Nesse sentido, segundo J ean Franco, o que a recente tendência teóric a do feminismo fez foi trazer para o campo acadêmico sujeitos por muito tempo marg ina liza dos socia Imente.

Direcionando seu olhar para a América Latina, Jean Franco, em Marcar diferenças, c ruzar fronteiras, mantém um constante diálogo com os reg imes dita toria is que passa ram a vigorar a partir da década de 1960. Tendo em vista que a s public ações orig ina is desses a rtig os oc orreram entre osanosde 1985 e 1992, podemoscrerque seu principal objetivo no agrupamento desses textos foi realizar uma pontual crítica a esse regime. Entretanto, é para o Méxic o que a autora despende grande parte de sua atenção, destacando a produção cultural mexicana e realizando constantes comparações entre o Méxic o revolucionário e a a tual situação do país.

Caracterizada dentro dos estudos de gênero, Jean Franco utiliza um grande número de teóricos/as que percorrem as mais variadas perspectivas como Homi Bhabba, Judith Butler, Pierre Bourdieu, Gilles Deleuze, Terry Eagleton, entre inúmeros outros autores e autoras. Com consta ntes crític as a o c a pita lismo, sua a ná lise está sempre associada ao rompimento de hierarquias de gênero, esfacelamento da divisão étnica, rompimento das camadas de classe, inteirando o público leitor de suas concepções políticas.

Os textos de Marcar diferenças, cruzar fronteiras estão longe de serem imparcia is. Em cada trec ho lido encontramosa autora presente, estimulando as mulheres a saírem da esfera privada e a adquirirem autoridade intelectual. Critic ando, debatendo, instigando, J ean Franco se faz militante em seus escritos, agrupando causas dos movimentos socia is em uma escrita acadêmica.

Maise Caroline Zucco Universidade Federal de Santa Catarina 